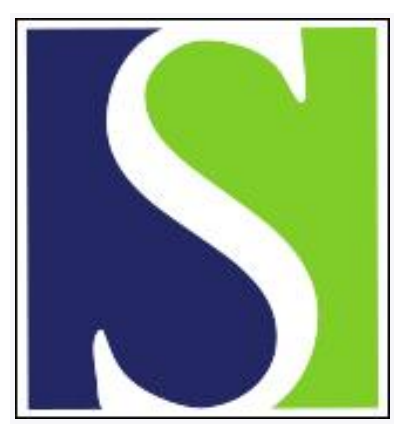

Scand J Work Environ Health 1996;22(5):374-380

https://doi.org/10.5271/sjweh.157

Issue date: Oct 1996

Three-year follow-up of serial nerve conduction among lead-exposed workers

by Chia S-E, Chia K-S, Chia H-P, Ong C-N, Jeyaratnam J

Key terms: blood lead; follow-up study; nerve conduction; serial result

This article in PubMed: www.ncbi.nlm.nih.gov/pubmed/8923612

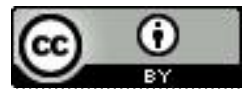




\title{
Three-year follow-up of serial nerve conduction among lead-exposed workers
}

\author{
by Sin-Eng Chia, MD, ${ }^{1}$ Kee-Seng Chia, MD, ${ }^{1}$ Hwee-Pin Chia, MMed(OM), Choon-Nam Ong, PhD, ${ }^{1}$
} Jerry Jeyaratnam, $M D^{\prime}$

\begin{abstract}
Chia S-E, Chia K-S, Chia H-P, Ong C-N, Jeyaratnam J. Three-year follow-up of serial nerve conduction among lead-exposed workers. Scand J Work Environ Health 1996;22:374—80.
\end{abstract}

\begin{abstract}
Objectives The purpose of this study was to investigate the serial nerve conduction parameters of a group of lead-exposed workers and determine their correlation with the serial blood lead results over a three-year period. A "nonresponse" level (defined as no significant changes in the nerve conduction in response to changes in the blood lead level of each exposed worker observed over the period of study) was also determined for blood lead in respect to the peripheral nerves.

Methods Seventy-two male workers from a lead battery manufacturing factory were followed at six-month intervals for three years. At each follow-up, the blood lead level was determined and nerve conduction tests (ulnar and median nerves) were conducted. A group of 82 unexposed subjects served as referents.

Results Significant differences were observed for some of the mean values of the median nerve conduction parameters between the exposed and reference groups. The 28 exposed workers who completed the follow-up were divided into the following two blood lead categories: $<40 \mu \mathrm{g} \cdot 100 \mathrm{ml}^{-1}\left(<1.93 \mu \mathrm{mol} \cdot \mathrm{l}^{-1}\right)$ and $\geq 40 \mu \mathrm{g}$. $100 \mathrm{ml}^{-1}\left(\geq 1.93 \mu \mathrm{mol} \cdot \mathrm{l}^{-1}\right)$. In the latter, the median motor conduction velocity, median distal latency, median amplitude, ulnar motor conduction velocity, and ulnar amplitude were significantly correlated (adjusted for age and within-subject variation) with the blood lead levels, but not so in the former.

Conclusions According to the three-year serial results, the "nonresponse" level for blood lead with respect to the peripheral nerves would be $<40 \mu \mathrm{g} \cdot 100 \mathrm{ml}^{-1}\left(<1.93 \mu \mathrm{mol} \cdot \mathrm{l}^{-1}\right)$.
\end{abstract}

Key terms blood lead, follow-up study, nerve conduction, serial results.

To our knowledge, only three epidemiologic studies (13) have been published that concern the potential neurologic effects of lead exposure and report repeated prospective testing of the same adults. However, there were shortcomings in these studies. In the study by Spivey et al (1), the referents could have been exposed to lead and other neurotoxic metals in aluminum processing plants. The study of Araki et al (2) suffered from small numbers (19 gun metal foundry workers) and the exposed workers were also exposed to elevated levels of zinc and copper, which may antagonize the effect of the lead (4). Similarly, Seppäläinen \& Hernberg (3) reported no significant differences between referents and 11 exposed workers after four years of exposure. One possible explanation given by the authors was the small number of subjects left at the end of the study.

To date, there is no report of a sufficiently large cohort of lead-exposed workers for which serial measurement of the nerve conduction parameters and the blood lead level (B-Pb) have been studied. The objectives of our study were (i) to study the serial nerve conduction values of a group of lead-exposed workers and correlate them with the serial blood lead results over a three-year period and (ii) to determine a "nonresponse" level for blood lead in respect to the peripheral nerves. The term "nonresponse" used in this study is defined as no significant changes in the nerve conduction parameters in response to changes in the blood lead level for each exposed worker observed over the period of study.

\section{Material and methods}

\section{Study population}

The exposed population consisted of 72 male workers from a lead battery manufacturing factory. The workers were involved in the smelting of lead ingots, lead past-

Department of Community, Occupational \& Family Medicine, National University of Singapore.

Reprint requests to: Dr Sin-Eng Chia, Department of Community, Occupational \& Family Medicine, National University of Singapore, National University Hospital, Lower Kent Ridge Road, Singapore 0511, Republic of Singapore. 
ing, and the forming, assembling and welding of the battery connectors. The workers are usually rotated through these various sections and had had considerable exposure throughout their work life.

The reference group consisted of 82 male factory workers who were undergoing a preemployment medical examination. None of the referents had any significant history of exposure to lead or any known neurotoxic substances.

The exposed and reference subjects were selected according to the following criteria: (i) no history of any metabolic diseases, for example, diabetes mellitus or thyrotoxicosis, (ii) clinically normal, and (iii) no alcohol consumption of more than $50 \mathrm{~g}$ of alcohol per day.

The 72 workers were followed at six-month intervals, by occupational physicians as part of a compulsory medical examination for workers exposed to lead (5). At each examination, blood was taken for analysis. A nerve conduction test was carried out for each of the workers by the same technician throughout the study period of three years (1992-1994). Although we started with 72 workers, only 28 completed the three-year period. Table 1 gives a breakdown of the numbers of exposed subjects studied at six-month intervals and their corresponding geometric mean B-Pb levels.

The original study protocol was to follow the 82 referents throughout the three-year period. Unfortunately, as the study was strictly voluntary, at the end of the first year only 26 subjects were still in the study. Only four subjects completed the three-year period. As such, the serial results of the referents have not been used in the subsequent analysis of the serial data.

The basic characteristics of the study population are presented in table 2 . No marked differences were noted in the age and alcohol intake of the referents, all the exposed subjects and the exposed subjects who completed the three-year follow-up. There was a higher percentage of Malay and smokers among the exposed workers. The mean $\mathrm{B}-\mathrm{Pb}$ for the reference group was 10.5 (range
4.4-19.8) $\mu \mathrm{g} \cdot 100 \mathrm{ml}^{-1}$. There were no marked differences in the group of workers who dropped out before the end of the three-year period.

\section{Biological measurements}

A blood sample was obtained by venepuncture with leadfree disposable syringes and stored in lead-free bottles at each examination. The $\mathrm{B}-\mathrm{Pb}$ was determined using an atomic absorption spectrophotometer with a granite furnace. External quality control was carried out under a quality assessment scheme (NEQAS) in the United Kingdom. Table 3 shows the accuracy in determining $\mathrm{B}-\mathrm{Pb}$ since 1985 .

\section{Nerve conduction methods}

The nerve conduction studies were performed for each subject by the same technician (throughout the study period) from a neurology laboratory. The measurements were made with a Medelec electrophysiological system (Model MS6). The room temperature was maintained constantly at $30-31^{\circ} \mathrm{C}$ and skin impedance was kept below $10 \mathrm{k} \Omega$ for all the recordings.

The maximum motor conduction velocity and distal motor latency of the median and ulnar nerves were determined in the dominant forearms. The median motor con-

Table 1. Mean blood lead levels of the exposed subjects at the time of the nerve conduction tests. (GSD = geometric standard deviation)

\begin{tabular}{lccc}
\hline $\begin{array}{l}\text { Nerve } \\
\text { conduction tests }\end{array}$ & $N$ & \multicolumn{2}{c}{$\begin{array}{c}\text { Blood lead concentration } \\
\left(\mu g \cdot 100 \mathrm{ml}^{-1}\right)\end{array}$} \\
\cline { 2 - 3 } & & $\begin{array}{c}\text { Geometric } \\
\text { mean }\end{array}$ & GSD $^{b}$ \\
\hline 1 & 72 & 36.9 & 0.35 \\
2 & 51 & 41.4 & 0.30 \\
3 & 45 & 42.4 & 0.33 \\
4 & 41 & 40.4 & 0.31 \\
5 & 36 & 41.4 & 0.27 \\
6 & 28 & 36.9 & 0.35 \\
\hline
\end{tabular}

a The nerve conduction tests were conducted at six-month intervals.

Table 2. Basic characteristics of the study population. ( $\left.1 \mu \mathrm{g} \cdot 100 \mathrm{ml}^{-1}=0.0483 \mu \mathrm{mol} \cdot \mathrm{l}^{-1}\right)$

\begin{tabular}{|c|c|c|c|c|c|c|c|c|c|c|c|c|c|c|c|c|c|c|c|c|c|}
\hline \multirow[t]{3}{*}{ Group } & \multirow{3}{*}{$\begin{array}{l}\text { Sub- } \\
\text { jects } \\
\text { (N) }\end{array}$} & \multirow{2}{*}{\multicolumn{2}{|c|}{$\begin{array}{c}\text { Age } \\
\text { (years) }\end{array}$}} & \multicolumn{6}{|c|}{ Ethnic group } & \multicolumn{4}{|c|}{ Alcohol intake } & \multicolumn{4}{|c|}{ Smoking } & \multirow{2}{*}{$\begin{array}{l}\text { Duration } \\
\text { of service } \\
\text { (years) }\end{array}$} & \multirow{2}{*}{\multicolumn{3}{|c|}{$\begin{array}{c}\text { Current } \\
\text { concentration of } \\
\text { blood lead } \\
\left(\mu \mathrm{g} \cdot 100 \mathrm{ml}^{-1}\right)\end{array}$}} \\
\hline & & & & \multicolumn{2}{|c|}{ Chinese } & \multicolumn{2}{|c|}{ Malay } & \multicolumn{2}{|c|}{ Indian } & \multicolumn{2}{|c|}{ Teetotaler } & \multicolumn{2}{|c|}{$\begin{array}{l}\text { Social } \\
\text { drinker }\end{array}$} & \multicolumn{2}{|c|}{ Yes } & \multicolumn{2}{|c|}{ No } & & & & \\
\hline & & Mean & $\mathrm{SD}$ & N & $\%$ & N & $\%$ & $\mathrm{~N}$ & $\%$ & $N$ & $\%$ & $N$ & $\%$ & N & $\%$ & $N$ & $\%$ & Mean SD & $\begin{array}{l}\text { Geo- } \\
\text { metric } \\
\text { mean }\end{array}$ & Range & Median \\
\hline All Exposed workers & 72 & 29.7 & 7.5 & 27 & 37.5 & 34 & 47.2 & 11 & 15.3 & 56 & 77.8 & 16 & 22.2 & 30 & 41.7 & 42 & 58.3 & $5.3 \quad 6.3$ & 36.9 & $7.3-68.5$ & 539.2 \\
\hline $\begin{array}{l}\text { Exposed workers who } \\
\text { completed the three-year } \\
\text { follow-up }\end{array}$ & 28 & 33.9 & 9.8 & 9 & 32.1 & 17 & 60.7 & 2 & 7.2 & 22 & 78.6 & 6 & 21.4 & 13 & 46.4 & 15 & 53.6 & $7.1 \quad 6.2$ & 39.72 & $23.3-8.1$ & 42.6 \\
\hline $\begin{array}{l}\text { Exposed workers who } \\
\text { dropped out before end } \\
\text { of the three-year } \\
\text { follow-up }\end{array}$ & 44 & 30.5 & 10.8 & 19 & 42.2 & 17 & 37.8 & 9 & 20.0 & 34 & 75.6 & 11 & 24.4 & 17 & 37.8 & 28 & 62.2 & 4.2 & 37.6 & $7.3-68.5$ & 536.7 \\
\hline Referents & 82 & 33.9 & 3.7 & 16 & 19.5 & 58 & 70.7 & 8 & 9.8 & 52 & 63.4 & 30 & 36.6 & 56 & 68.3 & 26 & 31.7 & . & 10.5 & $4.4-19.8$ & 810.5 \\
\hline
\end{tabular}


duction velocity and distal latency of the median nerve were obtained by stimulation of the median nerve at the wrist (13 $\mathrm{cm}$ from the base of the forefinger) and at the elbow. The ulnar motor conduction velocity and distal latency of the ulnar nerve were obtained by stimulation at the lateral aspect of the wrist $(10 \mathrm{~cm}$ from the base of the little finger) and just below the medial epicondyle. The muscle action potential of the thenar (for the median nerve) and hypothenar (for the ulnar nerve) muscles were recorded with surface disc electrodes.

The median maximum sensory nerve conduction velocity and median sensory amplitude were measured by stimulating the forefinger with ring electrodes and recording orthodromically at the wrist $(13 \mathrm{~cm}$ from the base of the forefinger) continuously for $10 \mathrm{~s}$. Action potentials from two sites along the nerves were picked up, amplified, and averaged. Artifacts causing overloaded signals, for example, introduced by muscle contraction in the region of the recording electrodes, were automatically rejected. Similarly, the ulnar maximum sensory nerve conduction velocity and the ulnar sensory amplitude were measured by stimulating the little finger with ring electrodes and recording orthodromically at the lateral aspect of the wrist $(10 \mathrm{~cm}$ from the base of the little finger).

In the base-line measurements made at the beginning of the study, there were significant differences in the

Table 3. Accuracy of the blood lead analyses. $\left(1 \mu \mathrm{g} \cdot 100 \mathrm{ml}^{-1}\right.$ $\left.=\left.0.0483 \mu \mathrm{mol} \cdot\right|^{-1}\right)$

\begin{tabular}{|c|c|c|c|}
\hline \multirow[t]{2}{*}{ Year } & \multirow[t]{2}{*}{$\begin{array}{c}\text { Range } \\
\left(\mu \mathrm{g} \cdot 100 \mathrm{ml}^{-1}\right)\end{array}$} & \multicolumn{2}{|c|}{$\begin{array}{l}\text { Mean absolute difference between } \\
\text { local and reference laboratories }\end{array}$} \\
\hline & & $\mu g \cdot 100 \mathrm{ml}^{-1}$ & $\%$ \\
\hline 1985 & $31.3-72.3$ & 2.94 & 6.13 \\
\hline 1986 & $23.4-71.7$ & 1.41 & 2.88 \\
\hline 1987 & $25.3-69.6$ & 1.94 & 3.99 \\
\hline 1988 & $27.1-73.1$ & 1.68 & 3.16 \\
\hline 1989 & $23.8-64.9$ & 2.88 & 6.49 \\
\hline 1990 & $18.9-68.4$ & 2.27 & 5.15 \\
\hline 1991 & $16.2-64.4$ & 1.82 & 4.68 \\
\hline 1992 & $18.4-60.3$ & 1.17 & 2.98 \\
\hline 1993 & $17.8-71.2$ & 1.15 & 2.76 \\
\hline 1994 & $17.9-69.7$ & 2.09 & 5.26 \\
\hline Overall & $16.2-73.1$ & 1.94 & 4.35 \\
\hline
\end{tabular}

median sensory nerve conduction velocity, median motor conduction velocity, median nerve, and median sensory amplitude means between the exposed and reference groups, even after adjustment for age, ethnic group, smoking and drinking habits in the ANCOVA (table 4). The ulnar nerve conduction values were not significantly different for the exposed workers and the referents, except for the ulnar nerve.

\section{Reproducibility of the serial nerve conduction parameters}

To ensure the reproducibility of the nerve conduction values, the nerve conduction values of seven healthy staff members of our department [with $\mathrm{B}-\mathrm{Pb}$ levels of $2.6-5.0 \mu \mathrm{g} \cdot 100 \mathrm{ml}^{-1}\left(0.12-0.24 \mu \mathrm{mol} \cdot \mathrm{1}^{-1}\right)$ and in the age range of $26-43$ years] were tested by the same procedure throughout the study period. Each person repeated the tests seven times. The analysis of the results of the seven subjects did not show any significant within-subject variation (table 5).

\section{Statistical analysis}

The distribution of the nerve conduction values, and B$\mathrm{Pb}$ levels were skewed. Logarithmic transformation was used to normalize the distribution. The mean nerve conduction values were compared between the exposed and reference subjects after adjustment for age, ethnic group, and smoking and drinking habits in an ANCOVA.

A cluster sample is often used to investigate the statistical relationship between numeric variables. Typically cluster sampling is carried out in the following two stages: sampling of clusters and then sampling of measurements within clusters. Standard regression analysis is often employed to estimate the regression parameters, namely, the intercept (alpha) and linear regression coefficient of $Y$ on $X$ (beta), for data from a clustered sample, for which the unit of analysis is a measurement $(X$ and $Y$ ) in which no consideration is given to the cluster identity of the measurements. This method is incorrect because standard regression stipulates that the $\mathrm{Y}$ measurements are statistically independent, whereas in a clus-

Table 4. Base-line neurophysiological data of the exposed and reference subjects. (NS = not significant)

\begin{tabular}{|c|c|c|c|c|c|c|c|c|c|c|c|}
\hline \multirow[t]{3}{*}{ Group } & \multicolumn{4}{|c|}{ Median Nerve } & \multicolumn{7}{|c|}{ Ulnar nerve } \\
\hline & $\begin{array}{l}\text { Sensory } \\
\text { conduction } \\
\text { velocity } \\
\left(\mathrm{ms}^{-1}\right) \\
\end{array}$ & $\begin{array}{c}\text { Motor } \\
\text { conduction } \\
\text { velocity } \\
\left(\mathrm{ms}^{-1}\right) \\
\end{array}$ & $\begin{array}{l}\text { Distal } \\
\text { latency } \\
\text { (ms) }\end{array}$ & $\begin{array}{l}\text { Amplitude } \\
(\mu \mathrm{V})\end{array}$ & \multicolumn{2}{|c|}{$\begin{array}{l}\text { Sensory } \\
\text { conduction } \\
\text { velocity } \\
\left(\mathrm{ms}^{-1}\right)\end{array}$} & \multicolumn{2}{|c|}{$\begin{array}{l}\text { Motor } \\
\text { conduction } \\
\text { velocity } \\
\left(\mathrm{ms}^{-1}\right)\end{array}$} & \multicolumn{2}{|c|}{$\begin{array}{l}\text { Distal } \\
\text { latency } \\
\text { (ms) }\end{array}$} & \multirow{2}{*}{$\begin{array}{c}\begin{array}{c}\text { Amplitude } \\
(\mu \mathrm{V})\end{array} \\
\text { Mean }^{a} \text { SE }\end{array}$} \\
\hline & Meana SE & Mean $^{\mathrm{a}}$ SE & Mean $^{a}$ SE & Mean' ${ }^{a}$ SE & Mean $^{\mathrm{a}}$ & SE & Meanta & SE & Mean $^{a}$ & SE & \\
\hline $\begin{array}{l}\text { Exposed }(\mathrm{N}=72) \\
\text { Reference }^{\mathrm{b}}(\mathrm{N}=82) \\
\text { P-values }\end{array}$ & $\begin{array}{ll}44.46 & 0.03 \\
50.44 & 0.04 \\
0.0001 & \end{array}$ & $\begin{array}{ll}53.84 & 0.02 \\
56.00 & 0.02 \\
0.0388\end{array}$ & $\begin{array}{ll}4.23 & 0.03 \\
3.87 & 0.03 \\
0.0002\end{array}$ & $\begin{array}{ll}15.93 & 0.08 \\
19.17 & 0.08 \\
0.0072 & \end{array}$ & $\begin{array}{l}42.43 \\
44.87 \\
\text { NS }\end{array}$ & $\begin{array}{l}0.04 \\
0.04\end{array}$ & $\begin{array}{l}55.34 \\
56.03 \\
\text { NS }\end{array}$ & $\begin{array}{l}0.02 \\
0.02\end{array}$ & $\begin{array}{l}3.33 \\
3.10 \\
0.0047\end{array}$ & $\begin{array}{l}0.02 \\
0.03\end{array}$ & $\begin{array}{ll}12.25 & 0.06 \\
12.68 & 0.06 \\
\text { NS } & \end{array}$ \\
\hline
\end{tabular}

a Adjusted geometric mean for age, ethnic group, and smoking and drinking habits in an analysis of covariance (ANCOVA).

b The reference group comprised the 82 unexposed subjects who attended the first nerve conduction test. 
Table 5. Nerve conduction values obtained in the tests for reproducibility. ${ }^{2}$

\begin{tabular}{|c|c|c|c|c|c|c|c|c|c|c|c|c|c|c|c|c|c|}
\hline \multirow[t]{3}{*}{ Subject } & \multirow{3}{*}{$\begin{array}{c}\text { Age } \\
\text { (years) }\end{array}$} & \multicolumn{8}{|c|}{ Median nerve } & \multicolumn{8}{|c|}{ Ulnar nerve } \\
\hline & & \multicolumn{2}{|c|}{$\begin{array}{c}\text { Sensory } \\
\text { conduction } \\
\text { velocity } \\
\left(\mathrm{ms}^{-1}\right) \\
\end{array}$} & \multicolumn{2}{|c|}{$\begin{array}{l}\text { Motor } \\
\text { conduction } \\
\text { velocity } \\
\left(\mathrm{ms}^{-1}\right)\end{array}$} & \multicolumn{2}{|c|}{$\begin{array}{l}\text { Distal } \\
\text { latency } \\
\text { (ms) }\end{array}$} & \multicolumn{2}{|c|}{$\begin{array}{l}\text { Amplitude } \\
(\mu V)\end{array}$} & \multicolumn{2}{|c|}{$\begin{array}{c}\text { Sensory } \\
\text { conduction } \\
\text { velocity } \\
\left(\mathrm{ms}^{-1}\right)\end{array}$} & \multicolumn{2}{|c|}{$\begin{array}{l}\text { Motor } \\
\text { conduction } \\
\text { velocity } \\
\left(\mathrm{ms}^{-1}\right) \\
\end{array}$} & \multicolumn{2}{|c|}{$\begin{array}{l}\text { Distal } \\
\text { latency } \\
\text { (ms) }\end{array}$} & \multicolumn{2}{|c|}{$\begin{array}{l}\text { Amplitude } \\
(\mu \mathrm{V})\end{array}$} \\
\hline & & Mean & $\mathrm{SO}$ & Mean & $S D$ & Mean & $S D$ & Mean & $\mathrm{SD}$ & Mean & SD & Mean & SD & Mean & $S D$ & Mean & SD \\
\hline$A$ & 37 & 52.0 & 1.7 & 61.3 & 2.6 & 3.5 & 0.3 & 16.4 & 1.3 & 46.7 & 1.8 & 62.1 & 2.6 & 3.0 & 0.5 & 10.7 & 1.5 \\
\hline B & 43 & 47.6 & 4.5 & 58.2 & 1.3 & 4.2 & 0.2 & 14.6 & 1.7 & 45.2 & 4.5 & 59.4 & 2.3 & 2.8 & 0.40 & 15.1 & 2.8 \\
\hline $\mathrm{C}$ & 23 & 50.4 & 3.2 & 61.5 & 2.8 & 3.2 & 0.3 & 24.6 & 2.2 & 44.3 & 3.2 & 61.6 & 2.8 & 2.9 & 0.3 & 15.7 & 1.3 \\
\hline D & 30 & 49.6 & 1.4 & 60.2 & 1.4 & 4.0 & 0.2 & 13.4 & 1.3 & 44.2 & 3.2 & 61.9 & 2.8 & 3.0 & 0.2 & 15.9 & 3.0 \\
\hline $\mathrm{E}$ & 30 & 55.5 & 1.9 & 60.9 & 1.8 & 3.5 & 0.2 & 19.4 & 2.2 & 43.2 & 1.4 & 57.5 & 1.5 & 2.9 & 0.1 & 9.1 & 1.3 \\
\hline $\mathrm{F}$ & 31 & 50.2 & 2.9 & 57.2 & 2.3 & 3.8 & 0.2 & 19.6 & 2.5 & 42.9 & 4.0 & 60.6 & 2.0 & 2.8 & 0.2 & 12.3 & 1.6 \\
\hline G & 26 & 54.7 & 2.0 & 60.4 & 2.5 & 3.2 & 0.3 & 25.9 & 3.9 & 49.1 & 2.7 & 61.5 & 1.6 & 2.6 & 0.3 & 19.3 & 2.8 \\
\hline
\end{tabular}

a None of the nerve conduction parameters had a significant within-subject variation.

tered sample the $\mathrm{Y}$ measurements tend to be more alike within a cluster than between clusters.

The method used in the analysis of the serial nerve conduction values and the $\mathrm{B}-\mathrm{Pb}$ levels (which was a clustered sample) was based on the analytic method used by econometricians (6). The analysis of the within-cluster regression coefficient was done by the statistical analysis system package (7) together with SAS codes, packaged as a macro (8).

The exposed subjects who completed the three-year follow-up were thus selected for the analysis of the within-cluster regression coefficients of the serial nerve conduction and the $\mathrm{B}-\mathrm{Pb}$ levels. To assess the "nonresponse" effect, the $\mathrm{B}-\mathrm{Pb}$ levels of the 28 exposed subjects were divided into different categories. Each category was then tested using the "within-cluster" package to see if there was any relationship between the nerve conduction values and the $\mathrm{B}-\mathrm{Pb}$ levels.

\section{Results}

Indices of exposure and the responses in nerve conduction

Table 6 shows the serial measurement data for the nerve conduction parameters and $\mathrm{B}-\mathrm{Pb}$ levels. The mean $\mathrm{B}-\mathrm{Pb}$ levels for the group peaked in the third test $[48.3 \mu \mathrm{g}$. $\left.100 \mathrm{ml}^{-1}\left(0.14 \mu \mathrm{mol} \cdot \mathrm{l}^{-1}\right)\right]$ and corresponded to a decrease in the median sensory nerve conduction velocity and ulnar sensory nerve conduction velocity in the fourth test (ie, six months after the third test was conducted) (table 6).

The relationship between the $\mathrm{B}-\mathrm{Pb}$ levels and the nerve conduction values is shown in table 7 . When the results of all the analyses $(\mathrm{N}=168)$ of the 28 workers who completed the follow-up are included, the regression correlation coefficients ( $\mathrm{r}$ ) (range from 0.17 to 0.31 ) were significant for most of the parameters except the median motor conduction velocity, ulnar sensory nerve conduction velocity and ulnar sensory amplitude. For the B-Pb level $\geq 40 \mu \mathrm{g} \cdot 100 \mathrm{ml}^{-1}$ [mean B-Pb $49.7 \mu \mathrm{g}$. $\left.100 \mathrm{ml}^{-1}\left(2.40 \mu \mathrm{mol} \cdot \mathrm{I}^{-1}\right)\right]$, the regression correlation $\mathrm{co}^{-}$ efficients were mainly in the range of 0.20 to 0.32 . However, for $\mathrm{B}-\mathrm{Pb}$ of $<40 \mu \mathrm{g} \cdot 100 \mathrm{~m}^{-1}$ [mean $\mathrm{B}-\mathrm{Pb}=$ $\left.32.6 \mu \mathrm{g} \cdot 100 \mathrm{ml}^{-1}\left(1.58 \mu \mathrm{mol} \cdot \mathrm{l}^{-1}\right)\right]$, there was hardly any association, especially for the ulnar nerve parameters. Even for the median nerve conduction parameters, the regression correlation coefficients were of smaller magnitudes for the lower B-Pb category. Because of the small number of workers (28 left) and the three-year period and narrow $\mathrm{B}-\mathrm{Pb}$ range, we could not divide the $\mathrm{B}-\mathrm{Pb}$ levels into more groups. Neither could we group the workers by a certain maximum $\mathrm{B}-\mathrm{Pb}$. Therefore,

Table 6. Serial neurophysiological data and blood lead levels of the exposed subjects at the six-month intervals over the three-year period. $\left(1 \mu \mathrm{g} \cdot 100 \mathrm{ml}^{-1}=0.0483 \mu \mathrm{mol} \cdot \mathrm{l}^{-1}\right)$

\begin{tabular}{|c|c|c|c|c|c|c|c|c|c|c|c|c|c|c|c|c|c|c|}
\hline \multirow[t]{3}{*}{ Test } & \multicolumn{8}{|c|}{ Median nerve } & \multicolumn{8}{|c|}{ Ulnar nerve } & \multirow{2}{*}{\multicolumn{2}{|c|}{$\begin{array}{c}\text { Blood lead } \\
\left(\mu \mathrm{g} \cdot 100 \mathrm{ml}^{-1}\right.\end{array}$}} \\
\hline & \multicolumn{2}{|c|}{$\begin{array}{l}\text { Sensory } \\
\text { conduction } \\
\text { velocity } \\
\left(\mathrm{ms}^{-1}\right)\end{array}$} & \multicolumn{2}{|c|}{$\begin{array}{l}\text { Motor } \\
\text { conduction } \\
\text { velocity } \\
\left(\mathrm{ms}^{-1}\right)\end{array}$} & \multicolumn{2}{|c|}{$\begin{array}{l}\text { Distal } \\
\text { latency } \\
\text { (ms) }\end{array}$} & \multicolumn{2}{|c|}{$\begin{array}{l}\text { Amplitude } \\
\qquad(\mu \mathrm{V})\end{array}$} & \multicolumn{2}{|c|}{$\begin{array}{l}\text { Sensory } \\
\text { conduction } \\
\text { velocity } \\
\left(m s^{-1}\right)\end{array}$} & \multicolumn{2}{|c|}{$\begin{array}{l}\text { Motor } \\
\text { conduction } \\
\text { velocity } \\
\left(\mathrm{ms}^{-1}\right)\end{array}$} & \multicolumn{2}{|c|}{$\begin{array}{c}\text { Distal } \\
\text { latency } \\
\text { (ms) }\end{array}$} & \multicolumn{2}{|c|}{$\begin{array}{l}\text { Amplitude } \\
(\mu V)\end{array}$} & & \\
\hline & Mean & SD & Mean & SD & Mean & $\mathrm{SD}$ & Mean & SD & Mean & $\mathrm{SD}$ & Mean & SD & Mean & SD & Mean & SD & Mean & $\mathrm{SD}$ \\
\hline 1st & 46.0 & 5.5 & 54.3 & 4.8 & 4.3 & 0.6 & 14.6 & 5.4 & 42.1 & 9.8 & 56.1 & 6.9 & 3.3 & 0.4 & 11.3 & 4.3 & 41.5 & 9.4 \\
\hline 2nd & 46.3 & 5.2 & 52.8 & 6.3 & 4.1 & 0.6 & 14.9 & 7.7 & 44.8 & 4.8 & 55.2 & 5.6 & 3.2 & 0.3 & 10.9 & 4.5 & 44.5 & 10.8 \\
\hline $3 \mathrm{rd}$ & 47.8 & 5.7 & 54.8 & 4.3 & 4.1 & 0.5 & 16.9 & 8.6 & 46.2 & 6.1 & 57.3 & 5.0 & 2.8 & 0.3 & 11.5 & 4.8 & 48.3 & 11.4 \\
\hline 4 th & 45.7 & 5.1 & 54.8 & 4.1 & 4.0 & 0.5 & 16.7 & 9.3 & 43.7 & 4.6 & 57.9 & 4.5 & 2.8 & 0.3 & 11.4 & 4.1 & 44.6 & 10.5 \\
\hline 5 th & 45.6 & 6.4 & 55.3 & 4.1 & 4.1 & 0.8 & 14.2 & 6.8 & 44.0 & 5.4 & 57.6 & 4.3 & 2.7 & 0.3 & 10.2 & 3.8 & 41.1 & 8.1 \\
\hline 6 th & 44.1 & 4.7 & 54.8 & 3.2 & 4.2 & 0.7 & 14.5 & 7.5 & 43.6 & 4.3 & 57.7 & 3.2 & 2.8 & 0.3 & 12.0 & 4.5 & 40.7 & 8.5 \\
\hline
\end{tabular}


Table 7. Age and within-cluster adjusted regression correlation coefficients between the conduction values and the blood lead $\mathrm{B}-\mathrm{Pb}$ levels at the end of the three-year follow-up of the $28 \mathrm{ex}$ posed workers who completed the study. $\left(1 \mu \mathrm{g} \cdot 100 \mathrm{ml}^{-1}=\right.$ $\left.\left.0.0483 \mu \mathrm{mol} \cdot\right|^{-1}\right)$

\begin{tabular}{lccc}
\hline & $\begin{array}{c}\text { All B-Pb } \\
\text { levels }\end{array}$ & $\begin{array}{c}\mathrm{B}-\mathrm{Pb}<40 \mu \mathrm{g} \cdot \mathrm{BPb} \geq 40 \mu \mathrm{g} \\
100 \mathrm{ml}^{-1}\end{array}$ \\
$100 \mathrm{ml}^{-1}$
\end{tabular}

some workers have been included in both categories. There were only 17 observations of a $\mathrm{B}-\mathrm{Pb}$ level of $<30 \mu \mathrm{g} \cdot 100 \mathrm{ml}^{-1}\left(<1.44 \mu \mathrm{mol} \cdot 1^{-1}\right)$ and 41 observations at a $\mathrm{B}-\mathrm{Pb}$ level of $>50 \mu \mathrm{g} \cdot 100 \mathrm{ml}^{-1}\left(2.42 \mu \mathrm{mol} \cdot \mathrm{I}^{-1}\right)$.

\section{Discussion}

The mean $\mathrm{B}-\mathrm{Pb}$ for the exposed workers was $36.9 \mu \mathrm{g} \cdot 100 \mathrm{ml}^{-1}\left(1.78 \mu \mathrm{mol} \cdot \mathrm{1}^{-1}\right)$. At this level, significant differences where observed for all the median nerve conduction parameters of the exposed workers when they were compared with the referents. However, there was no significant difference in the ulnar nerve conduction parameters of the exposed workers and the referents (except for distal latency). Therefore the median nerve appeared to be more susceptible to lead effects than the ulnar nerve. Davis \& Svendsgaard, in a critical review and meta-analysis of nerve conduction studies and lead workers (9), also reported on this apparent susceptibility of the median nerve to lead. We will not comment on this phenomenon further as the susceptibility of the median nerve and the measurement of distal latency have been discussed in an earlier paper (10). However, we would like to stress that our finding is unlikely to be confounded by carpal tunnel syndrome among the exposed workers. First, the exposed workers were not subjected to repetitive work since they are rotated through various sections of the factory (as mentioned earlier). Furthermore, none of the workers complained of paresthesia, numbness, or weakness of their fingers. Thus far, there have been no reports of workers with work-related carpal tunnel syndrome in Singapore from the manufacturing of car batteries although it is a notifiable disease under the Workmen's Compensation Act of 1975 (11).

Ehle (12) reviewed 15 articles on the correlation of $\mathrm{B}-\mathrm{Pb}$ and nerve conduction velocity. He concluded: "In summary, it would appear from review of all the studies of blood lead levels versus nerve conduction velocity that the majority of studies do not support a continuous relationship between blood lead and nerve conduction velocity in adults at blood lead levels below $70 \mu \mathrm{g} / 100 \mathrm{ml}(3.39 \mu \mathrm{mol} / \mathrm{l})[\mathrm{p} 211]$ " (12). The statement made by Ehle involved studies correlating current $\mathrm{B}-\mathrm{Pb}$ levels with nerve conduction velocities. Peripheral neuropathy caused by lead is usually associated with chronic lead exposure rather than with acute exposure, unless the exposure is very high (13). Indeed our result (table 6) reinforced the point that it takes time for the effects of lead on nerve conduction parameters to be seen. Although the mean $\mathrm{B}-\mathrm{Pb}$ levels for the group peaked in the third test $\left[48.3 \mu \mathrm{g} \cdot 100 \mathrm{ml}^{-1}\left(2.33 \mu \mathrm{mol} \cdot \mathrm{l}^{-}\right)^{1}\right]$, the corresponding decrease in the median sensory nerve conduction velocity and ulnar sensory nerve conduction velocity was only observed in the fourth test (ie, six months after the third test was conducted) (table 6). As damage of the peripheral nerves takes time, it would be more objective to look at serial $\mathrm{B}-\mathrm{Pb}$ levels rather than current $\mathrm{B}-\mathrm{Pb}$ values to determine the effect of lead on the peripheral nervous system.

One of the drawbacks of this study on serial nerve conduction tests and $\mathrm{B}-\mathrm{Pb}$ results is the lack of a reference group (with serial readings) for comparison. A reference group of 82 subjects was followed at the beginning of the study, but only four remained at the end of the three-year period. Although a reference group was not available, a small group of seven subjects were followed throughout the study period. No significant within-subject variation was observed for the nerve conduction parameters studied, and this finding demonstrates the repeatability of the nerve conduction tests collected throughout the study. Furthermore, it would have been highly unlikely for the reference group to have had a wide fluctuation in their $\mathrm{B}-\mathrm{Pb}$ levels if they had been followed up, as they were not exposed to lead. Thus the objectives of this study could still be studied without a reference group to observe the serial results of the nerve conduction parameters and $\mathrm{B}-\mathrm{Pb}$ levels.

Another concern is related to the high attrition rate of the exposed group - from an initial number of 72 to 28 workers. The high attrition rate was unavoidable as the study was strictly voluntary and workers who left the company, usually for a better paying job, were not keen to be followed further. The profiles of the workers who left were fairly similar to those who completed the study with respect to their mean $\mathrm{B}-\mathrm{Pb}$ levels, exposure duration, and mean age (table 2). Thus these workers were not very different from those who completed the study. 
One of the objectives of this research was to study the serial results of the nerve conduction parameters and the association with $\mathrm{B}-\mathrm{Pb}$ levels. We have shown that certain nerve conduction parameters correlate significantly with $\mathrm{B}-\mathrm{Pb}$ levels over a three-year period when adjusted for age and within-subject variation in nerve conduction (table 7). The correlation coefficients for the $\mathrm{B}-\mathrm{Pb}$ level and the median nerve conduction parameters were stronger than for the $\mathrm{B}-\mathrm{Pb}$ levels and the ulnar nerve conduction parameters. Again, the serial results showed that the median nerve is more susceptible to the effects of lead than the ulnar nerve is.

In the group of exposed workers with a $\mathrm{B}-\mathrm{Pb}$ level of $\geq 40 \mu \mathrm{g} \cdot 100 \mathrm{ml}^{-1}$, the age and within-cluster adjusted regression correlation coefficients of the median motor conduction velocity, median nerve, median sensory amplitude, and ulnar sensory nerve conduction velocity were significantly correlated with the $\mathrm{B}-\mathrm{Pb}$ levels and of a larger magnitude than that of the group with a $\mathrm{B}-\mathrm{Pb}$ of $<40 \mu \mathrm{g} \cdot 100 \mathrm{ml}^{-1}$ (table 4 ). In addition, the group with a $\mathrm{B}-\mathrm{Pb}$ of $<40 \mu \mathrm{g} \cdot 100 \mathrm{ml}^{-1}$, the adjusted regression correlation coefficients were not significant.

Spivey et al (1) studied 55 lead-exposed workers and 31 referents initially and after $12-18$ months of lead exposure. There were no significant changes from the initial to the final values for the ulnar motor and sensory and the peroneal motor and sural sensory nerve conduction velocities. However, the referents' (aluminumprocessing workers) mean $\mathrm{B}-\mathrm{Pb}$ level was $22.1 \mu \mathrm{g}$. $100 \mathrm{ml}^{-1}\left(1.07 \mu \mathrm{mol} \cdot \mathrm{I}^{-1}\right)$, which subsequently increased to $27.9 \mu \mathrm{g} \cdot 100 \mathrm{ml}^{-1}\left(1.35 \mu \mathrm{mol} \cdot \mathrm{l}^{-1}\right)$ in a year's time. The referents could have been exposed to lead and other neurotoxic metals in the aluminum-processing and therefore the results could have been confounded. Although the $\mathrm{B}-\mathrm{Pb}$ analyses were done on a monthly basis (for most workers), no attempts were made to study the subjects' nerve conduction serially.

Nineteen gun metal foundry workers were studied by Araki et al over a two-year period (2). Motor and sensory conduction velocities of the distal radial and median nerves, together with the $\mathrm{B}-\mathrm{Pb}$ level, were measured twice in a 12-month interval. They reported that yearly changes in the motor conduction velocity of the radial nerve and the sensory conduction velocity of the median nerve (forearm) were inversely related to the change in alcohol ingestion rather than to the lead levels. It must be noted that the exposed workers were also exposed to elevated levels of zinc and copper, which may antagonize the effect of lead (4). This possibility may explain the negative findings.

Seppalainen \& Hernberg (3) studied both median and ulnar motor and sensory conduction in 23 lead workers after the initial year of lead exposure (3). Fifteen of these men were available for restudy after two years of exposure, and 11 were restudied after four years. At one year, the median motor distal latency and sensory distal conduction were significantly slower than in the matched referents. At two years both the median sensory distal conduction and forearm sensory conduction were significantly slower, but the median motor distal latency was no longer slower. No significant differences were present between the referents and the 11 exposed workers after four years of exposure. The inconclusive result of the study is probably a result of a lack of power, as there were only 11 exposed workers at the end of the fourth year (15).

Hernberg et al, in a summary article on the same study (15), reported that a slowing of the nerve conduction velocities occurred only for the lead workers whose maximal $\mathrm{B}-\mathrm{Pb}$ levels were between $30\left(1.45 \mu \mathrm{mol} \cdot \mathrm{l}^{-1}\right)$ and $50\left(2.42 \mu \mathrm{mol} \cdot \mathrm{l}^{-1}\right) \mu \mathrm{g} \cdot 100 \mathrm{ml}^{-1}(15)$. Those with a $\mathrm{B}-\mathrm{Pb}$ level below $30 \mu \mathrm{g} \cdot 100 \mathrm{ml}^{-1}$ for up to two years had no significant changes in their nerve functions; their average nerve conduction velocities remained at the initial level and also at the level of the referents.

Our findings are similar to those of Hernberg et al (15). In the category of $\mathrm{B}-\mathrm{Pb} \geq 40 \mu \mathrm{g} \cdot 100 \mathrm{ml}^{-1}$, with a mean $\mathrm{B}-\mathrm{Pb}$ of $49.7 \mu \mathrm{g} \cdot 100 \mathrm{ml}^{-1}\left(2.40 \mu \mathrm{mol} \cdot \mathrm{l}^{-1}\right)$, there were significant correlations of the median motor conduction velocity, median distal latency, and ulnar motor conduction velocity data with the $\mathrm{B}-\mathrm{Pb}$ levels. This significant correlation was observed for up to a three-year period (adjusted for age and within-subject variation). The other nerve conduction parameters were not significantly correlated. This result is consistent with the knowledge that motor nerves are more susceptible to the effects of lead than the sensory nerves are. It also shows that a $\mathrm{B}-\mathrm{Pb}$ of $\geq 40 \mu \mathrm{g} \cdot 100 \mathrm{ml}^{-1}$ does affect the motor nerve conduction since there is slowing of both the median and ulnar motor conduction velocities with increases in the B-Pb levels.

In the category of $\mathrm{B}-\mathrm{Pb}<40 \mu \mathrm{g} \cdot 100 \mathrm{ml}^{-1}$, all the nerve conduction parameters correlated poorly with the $\mathrm{B}-\mathrm{Pb}$ levels. The subjects' median and ulnar nerves (for those parameters measured) were not affected at $\mathrm{B}-\mathrm{Pb}$ levels of $<40 \mu \mathrm{g} \cdot 100 \mathrm{ml}^{-1}$ within the three-year period. In light of the results of this study, we would like to suggest that the "nonresponse" level of blood lead could be considered to be $<40 \mu \mathrm{g} \cdot 100 \mathrm{ml}^{-1}$ with respect to the peripheral nerves. More studies are needed before our suggestion can be confirmed.

\section{Acknowledgments}

This study was supported by research grant RP 3900339 from the National University of Singapore. We thank Ms LH Chua and Mr HY Ong for their technical assistance. 


\section{References}

1. Spivey GH, Baloch RW, Brown CP. Subclinical effects of chronic increased lead absorption - a prospective study: III neurological findings at follow up examination. J Occup Med $1980 ; 22: 607-12$.

2. Araki S, Murata K, Uchida E, Anon H, Ozawa H. Radial and median nerve conduction velocities in workers exposed to lead, copper, and zinc: a follow-up study for 2 years. Environ Res 1993;61:308-16.

3. Seppalainen AM, Hernberg S. A follow up study of nerve conduction velocities in lead exposed workers. Neurobehav Toxicol Teratol 1982;4:721-3.

4. Murata K, Araki S, Aono H. Effects of lead, zinc, and copper absorption on peripheral nerve conduction in metal workers. Int Arch Occup Environ Health 1987;59:11 20.

5. Phoon WH, Chan OY. Statutory medical examinations and designated factory doctors in Singapore. J Soc Occup Med 1990;40:55-8

6. Gujarati D. Basic econometries. New York (NY): McGrawHill, 1978

7. SAS Institute. SAS/STAT user's guide, release 6.04 ed. Cary (NC): SAS Institute, 1990.

8. Lee J, Lee HP, Chia KS. Regression analysis of data from a repeated-measure sample. Presented at the 12th Asia-Pacific
Cancer Conference, 17-20 October 1995, Singapore.

9. Davis JM, Svendsgaard DJ. Nerve conduction velocity and lead: a critical review and meta-analysis. In: Johnson BL, editor. Advances in neurobehavioral toxicology: applications in environmental and occupational health. Chelsea (Ml) Lewis, 1990:353-76.

10. Chia SE, Chia HP, Ong CN, Jeyaratnam J. Cumulative blood lead levels and nerve conduction parameters. Occup Med $1996: 46: 59-64$

11. Government Gazette, Republic of Singapore. The workmen's compensation act 1975. Singapore: Singapore National Printers, 1975.

12. Ehle AL. Lead neuropathy and electrophysiological studies in low level lead exposure: a critical review. Neurotoxicology 1986;7:203-16

13. Lewis R. Metals. In: LaDou J, editor. Occupational medicine. San Francisco (CA): Appleton \& Lange 1990:297-326.

14. Seppalainen AM, Hernberg S, Vesanto R, Knock B. Early neurotoxic effects of lead exposure: a prospective study. Neurotoxicology 1983;4:181-92.

15. Hernberg S, Seppäläinen AM, Mantere P. A prospective study on early neurotoxic effects of lead. Ann Acad Med Singapore $1984 ; 13: 378-82$.

Received for publication: 22 January 1996 